\title{
Nitrogen, phosphorus, and potassium use efficiency for perennial ryegrass and white clover cultivar mixtures
}

\author{
Ma. Paulina Sánchez ${ }^{1}$, Hernán Acuña ${ }^{1 *}$, Luis Inostroza ${ }^{2}$, and Erick Zagal ${ }^{1}$ \\ ${ }^{1}$ Universidad de Concepción, Facultad de Agronomía, Av. Vicente Méndez 595, Chillán, Chile. \\ "Corresponding author (gacunap@udec.cl). \\ ${ }^{2}$ Instituto de Investigaciones Agropecuarias, INIA Quilamapu, Av. Vicente Méndez 515, Chillán, Chile.
}

Received: 4 December 2020; Accepted: 12 March 2021; doi:10.4067/S0718-58392021000300456

\begin{abstract}
The nutrient use efficiency of perennial ryegrass (Lolium perenne L.) (PR) and white clover (Trifolium repens L.) (WC) cultivars can affect the grass-legume compatibility of different cultivar combinations, thus impacting the sustainability of animal production systems, especially on marginal soils. The objective of this work was to evaluate $\mathrm{N}, \mathrm{P}$, and $\mathrm{K}$ absorption efficiency (NAE, PAE, and KAE) and use efficiency (NUE, PUE, and KUE). This study included two experiments with the same full factorial treatment structure (4 PR cultivars $\times 3 \mathrm{WC}$ cultivars) in a randomized complete block design under field conditions and a completely randomized pot design. The field cutting experiment was carried out on sites with two contrasting soil depths and the pot experiment was conducted under shade conditions. Results showed nonsignificant (P > 0.05) factor interactions for DM yield and both nutrient absorption and use efficiency. The NAE and PAE of PR 'Extreme' and 'Bealey' were higher under field conditions than pot conditions. In the field experiment, NAE of WC 'Will' $\left(2.33 \mathrm{~kg} \mathrm{DM} \mathrm{ha}^{-1} / \mathrm{mg} \mathrm{N} \mathrm{kg}^{-1}\right)$ tended to be similar $(\mathrm{P}<0.05)$ to other cultivars in deep soil, but was significantly higher $(\mathrm{P}<0.001)$ than 'Ladino' and 'Bounty' in shallow soil $\left(0.70 \mathrm{~kg} \mathrm{DM} \mathrm{ha}^{-1} / \mathrm{mg} \mathrm{kg}^{-1}\right)$. The evaluation of NUE and PUE under field conditions and KUE under pot conditions showed that PR 'Bealey' and WC 'Ladino' reached higher values. In conclusion, results showed a cultivar effect on nutrient use efficiency in PR/WC mixtures, which had an impact on PRWC compatibility, mainly due to the higher absorption efficiency of PR 'Bealey' and WC 'Will', both of which exhibited the highest degree of compatibility for total DM yield.
\end{abstract}

Key words: Absorption efficiency, grass-legume compatibility, use efficiency.

\section{INTRODUCTION}

The environmental cost of agricultural activities has increased due to the intensification of production systems to satisfy the growing demand for food (Barrett et al., 2015). The use of higher fertilizer rates in crops and pastures, particularly $\mathrm{N}, \mathrm{P}$, and $\mathrm{K}$, has been an important way to intensify food production; however, these fertilizers involve high energy consumption, usually from fossil fuels, for their production or extraction (Ramírez and Worrell, 2006). Therefore, it is urgent to research the nutrient use efficiency of forage species to find cheaper and more sustainable grassland production systems and germplasm that is better adapted to marginal soils. Improved nutrient use efficiency can reduce fertilizer consumption and the cost of animal production systems (Wilkins, 2008).

Nutrient use efficiency is defined as the ability of a genotype or cultivar to absorb and incorporate or use nutrients from the soil to produce aerial biomass and roots or other materials of economic value (Blair, 1993). According to Manschadi et al. (2014), it can usually be considered as the product of two subcomponents: (i) nutrient acquisition 
efficiency, which is total nutrients in the aboveground plant organs per unit of nutrient supply and (ii) nutrient use efficiency, which is crop seed yield per unit of nutrient uptake. These two components of nutrient use efficiency have also been described as absorption efficiency and use efficiency. Absorption efficiency, also called external efficiency, is the uptake of an amount of a nutrient per available unit of soil nutrient. Use efficiency, or internal efficiency, is the DM (grain or other product) yield per unit of nutrient absorbed, also referred to as conversion efficiency by many authors as found in a review by Lemaire and Ciampitti (2020). Cultivar characteristics and their interactions with environmental conditions, such as soil type, management practices, humidity, radiation, and temperature could affect nutrient efficiency (Lemaire and Ciampitti, 2020).

Pasture systems based on forage mixtures of perennial ryegrass (Lolium perenne L.) (PR) and white clover (Trifolium repens L.) (WC) are widely used in the temperate regions of the world because of their high productivity of nutrient-rich herbage and their persistence under grazing management (Annicchiarico et al., 2015; Inostroza et al., 2018). However, they need to be adapted to local environments, particularly in marginal areas (Acuña et al., 2016; Luscher et al., 2019). The search for compatible combinations of PR and WC cultivars play an important role in reaching this goal; cultivar nutrient use efficiency could significantly affect the ability of the two species to grow together and produce high herbage yields, which would be a characteristic of their compatibility (Suter et al., 2015). Overall, beneficial mixtures of legume and non-legume species respond to better use of the available growth resources due to species niche complementarity and positive interspecific interactions (Luscher et al., 2019).

In Chile, the PR and WC mixture is the primary forage resource for cattle and sheep production in irrigated areas with a Mediterranean climate and in humid regions (Acuña et al., 2016; Vásquez et al., 2018). This is because of its high productivity of forage with good nutritional value, tolerance to animal traffic, persistence, and low $\mathrm{N}$ fertilizer requirements (Jahufer et al., 2012; Annicchiarico et al., 2015). Perennial ryegrass needs high soil N availability to grow, while WC can fix significant amounts of atmospheric $\mathrm{N}$ through symbiotic $\mathrm{N}$ fixation, which can be transferred to ryegrass (Nyfeler et al., 2011). These differences are the key to understanding vegetative growth relationships between grass and clover in mixed swards (Thilakarathna et al., 2016; Luscher et al., 2019). Soil P and K availability also affects the competition between grass and clover, but to a lesser degree than $\mathrm{N}$. The ryegrass proportion in mixtures with WC increased and clover decreased when $\mathrm{P}$ and $\mathrm{K}$ soil availability improved in the absence of $\mathrm{N}$ shortage. When $\mathrm{N}$ is a limiting factor for ryegrass, clover becomes dominant until $\mathrm{N}$ availability increases because biological $\mathrm{N}$ is fixed by clover (Nyfeler et al., 2011). In addition, the total nutrient uptake from soil and fertilizer $(\mathrm{N}, \mathrm{P}$, and $\mathrm{K}$ ) is enhanced in grass-legume mixtures (Hoekstra et al., 2015; Husse et al., 2017). Large differences in P use efficiency were reported by Acuña and Inostroza (2013) for WC populations naturalized in Chile; these authors used these differences to select germplasm for breeding. Therefore, nutrient efficiency of PR and WC cultivars could be an important factor in understanding grass/clover performance and cultivar compatibility. However, there is no specific information on the use efficiency of N, P, and K of cultivars in highinterest mixed swards. Several cultivars of both species are offered without sufficient local information for farmers and consultants to choose the best combination of cultivars for their specific conditions.

Two experiments were initially conducted under field conditions in two soils at different depths and using different combinations of WC and PR cultivars. A pot experiment was conducted to check results without the presence of spontaneous species after the field work was completed. The nutrient use efficiency of perennial ryegrass, white clover, and their mixtures was tested under field and pot conditions to determine whether combinations of different cultivars of both species, with contrasting morphological and physiological traits, were affected and if these combinations could partly explain cultivar compatibility. The objective of these experiments was to determine the $\mathrm{N}, \mathrm{P}$, and $\mathrm{K}$ absorption and use efficiency of four perennial ryegrass cultivars, three white clover cultivars, and their mixtures (12 factorial combinations) under field and pot conditions.

\section{MATERIALS AND METHODS}

A field cutting experiment using two different soil depths and a pot experiment under shade conditions were conducted at the Instituto de Investigaciones Agropecuarias (INIA) in Chillán, Chile, to evaluate N, P, and K use efficiency of perennial ryegrass and white clover cultivar mixtures. 


\section{Plant material and experimental design}

The perennial ryegrass (Lolium perenne L.) (PR) cultivars were Bealey (endophyte NEA2, late flowering), Extreme (low natural endophyte, early flowering), Quartet (endophyte AR1, late flowering), and Banquet (high natural endophyte, late flowering). White clover (Trifolium repens L.) (WC) cultivars were Ladino Italia, Will, and Bounty, which are large-, medium-, and small-leaved types, respectively. Other cultivar characteristics of both species are described in Table 1.

Treatments (12) were grass/clover mixtures resulting from full factorial combinations of the four PR and three WC cultivars. A randomized complete block design was used in the field and a completely randomized design was used in the pot study, both with four replicates.

\section{Field experimental sites, soil preparation, and sowing}

The experiment was conducted at two sites at the INIA Santa Rosa Experimental Station (36³6’ S, 72 ${ }^{\circ} 02^{\prime}$ 'W) from 2009 to 2012. Soils at both sites are of volcanic origin with profile depths of $30 \mathrm{~cm}$ (shallow soil site, SSS) and $100 \mathrm{~cm}$ (deep soil site, DSS). Soils belong to medial over sandy skeletal, amorphic, thermic Humic Haploxerand (Pueblo Seco series) and medial, amorphic, thermic Humic Haploxerand (Arrayan series), respectively (Stolpe, 2006). The sites were located $300 \mathrm{~m}$ from each other in a field with flat topography. Initial nutrient availability and chemical characterization of soils

Table 1. Cultivar origin, ploidy, growth, and morphological characteristics of perennial ryegrass and white clover cultivars.

\begin{tabular}{|c|c|c|c|c|c|}
\hline \multirow[b]{2}{*}{ Cultivar } & \multicolumn{5}{|c|}{ Perennial ryegrass } \\
\hline & Leaf size & Precocity & $\begin{array}{l}\text { Seasonal production } \\
\text { concentration }\end{array}$ & Ploidy & Origin \\
\hline Bealey & Large & Late & Spring-Summer & $4 n$ & New Zealand \\
\hline Extreme & Medium & Early & Winter & $2 n$ & New Zealand \\
\hline Quartet & Large & Late & Spring-Summer & $4 n$ & New Zealand \\
\hline \multirow[t]{2}{*}{ Banquet } & Medium & Late & Winter- Summer & $4 n$ & New Zealand \\
\hline & \multicolumn{5}{|c|}{ White clover } \\
\hline Cultivar & \multicolumn{2}{|c|}{ Leaf size } & \multicolumn{2}{|l|}{ Growth habit } & Origin \\
\hline Ladino & \multicolumn{2}{|c|}{ Large } & Semi-erect & \multicolumn{2}{|r|}{ Italy } \\
\hline Will & \multicolumn{2}{|c|}{ Medium } & Semi-erect & \multirow{2}{*}{\multicolumn{2}{|c|}{$\begin{array}{l}\text { North Carolina, USA } \\
\text { New Zealand }\end{array}$}} \\
\hline Bounty & \multicolumn{2}{|c|}{ Small } & Prostrate & & \\
\hline
\end{tabular}

Table 2. Soil chemical analyses of the field experiment before soil preparation under deep soil site (DSS, $100 \mathrm{~cm})$ and shallow soil site $(\mathrm{SSS}, 30 \mathrm{~cm})$ conditions and soil used as substrate in the pot experiment (Pot) before sowing.

\begin{tabular}{|c|c|c|c|}
\hline Soil variable & DSS & SSS & Pot \\
\hline \multicolumn{4}{|l|}{ Nutrient availability } \\
\hline $\mathrm{pH}\left(\mathrm{H}_{2} \mathrm{O}\right)$ & 5.7 & 6.1 & 5.6 \\
\hline Organic matter, $\%$ & 10.2 & 10.0 & 11.0 \\
\hline $\mathrm{N}, \mathrm{mg} \mathrm{kg}^{-1}$ & 53.0 & 17.0 & 28.4 \\
\hline $\mathrm{P}, \mathrm{mg} \mathrm{kg}^{-1}$ & 23.2 & 16.4 & 8.3 \\
\hline $\mathrm{K}, \mathrm{mg} \mathrm{kg}^{-1}$ & 267.7 & 17.8 & 108.5 \\
\hline $\mathrm{S}, \mathrm{mg} \mathrm{kg}^{-1}$ & 14.0 & 12.8 & 13.1 \\
\hline \multicolumn{4}{|c|}{ Interchangeable bases } \\
\hline $\mathrm{Ca}, \mathrm{cmol}_{(+)} \mathrm{kg}^{-1}$ & 7.2 & 4.5 & 6.5 \\
\hline $\mathrm{Mg}, \mathrm{cmol}_{(+)} \mathrm{kg}^{-1}$ & 1.1 & 1.0 & 0.9 \\
\hline $\mathrm{K}, \mathrm{cmol}_{(+)} \mathrm{kg}^{-1}$ & 0.7 & 0.1 & 0.3 \\
\hline $\mathrm{Na}, \mathrm{cmol}_{(+)} \mathrm{kg}^{-1}$ & 0.1 & 0.2 & 0.2 \\
\hline $\mathrm{Al}, \mathrm{cmol}_{(+)} \mathrm{kg}^{-1}$ & 0.1 & 0.04 & 0.1 \\
\hline ECEC & 9.2 & 5.7 & 7.9 \\
\hline Al saturation, $\%$ & 0.7 & 0.7 & 0.9 \\
\hline \multicolumn{4}{|l|}{ Microelements } \\
\hline $\mathrm{Zn}, \mathrm{mg} \mathrm{kg}^{-1}$ & 0.7 & 0.6 & 0.7 \\
\hline $\mathrm{Fe}, \mathrm{mg} \mathrm{kg}^{-1}$ & 44.6 & 68.2 & 36.0 \\
\hline $\mathrm{Cu}, \mathrm{mg} \mathrm{kg}^{-1}$ & 1.5 & 1.7 & 1.1 \\
\hline $\mathrm{Mn}, \mathrm{mg} \mathrm{kg}^{-1}$ & 7.5 & 6.4 & 4.5 \\
\hline $\mathrm{B}, \mathrm{mg} \mathrm{kg}^{-1}$ & 0.7 & 0.4 & 0.7 \\
\hline
\end{tabular}

ECEC: Effective cation exchange capacity. 
before the experiments at the $0-15 \mathrm{~cm}$ depth are shown in Table 2. Soils at both sites were plowed 6 mo before sowing; weeds were controlled and the emergence of spontaneous WC was managed mechanically every 2 mo during this period. During seedbed preparation, $2 \mathrm{tha}^{-1}$ lime and $15 \mathrm{~kg} \mathrm{ha}^{-1}$ boronatrocalcite $(10 \% \mathrm{~B})$ were mixed with the topsoil profile at both sites and 300 and $400 \mathrm{~kg} \mathrm{ha}^{-1}$ triple superphosphate $\left(46 \% \mathrm{P}_{2} \mathrm{O}_{5}\right)$ at the DSS and SSS, respectively, to achieve similar soil fertility conditions at both sites before sowing. Sulfur and $\mathrm{Mg}$ were applied at sowing as $200 \mathrm{~kg} \mathrm{ha}^{-1}$ sulfate of potash magnesia $\left(22 \% \mathrm{~S}, 18 \% \mathrm{MgO}, 22 \% \mathrm{~K}_{2} \mathrm{O}\right.$; Sul-po-mag) and 50 and $100 \mathrm{~kg} \mathrm{~K} \mathrm{ha}^{-1}$ as potassium muriate $\left(60 \% \mathrm{~K}_{2} \mathrm{O}\right)$ to the DSS and SSS, respectively; these were placed under PR seeds $\left(20 \mathrm{~kg} \mathrm{ha}^{-1}\right)$ sown in rows (20 $\mathrm{cm}$ spacing) in April 2010. The WC seedlings were sown in seedbeds under greenhouse conditions during the winter and were acclimated before transplanting them to the field with $20 \mathrm{~cm}$ spacing between the PR rows in September 2010. Plot size was $1.6 \times 4.0 \mathrm{~m}$. Experimental plots were irrigated daily with an automatic pressurized system to replace the transpired water and maintain near field capacity at DSS and weekly by micro sprinkler irrigation at SSS from the beginning of the 20102011 growing season.

\section{Establishment and management of pot experiment}

The pot experiment was carried out in the spring and summer of the 2014-2015 growing season in Chillán (36³5' S, $72^{\circ} 05^{\prime} \mathrm{W}$ ). Soil from the $0-15 \mathrm{~cm}$ depth at DSS was used as substrate (nutrient availability shown in Table 2). The 4-L plastic pots ( $20 \mathrm{~cm}$ height, 23 and $18 \mathrm{~cm}$ top and bottom diameters, respectively) were filled with sifted dry soil $(<2 \mathrm{~mm}$ particle size) and $4 \mathrm{~kg}$ soil was allocated to each pot and watered to field capacity. Each pot was sown with $32 \mathrm{PR}$ and $8 \mathrm{WC}$ seeds at a 2-3 mm depth on 14 October 2014. After plant establishment (25 November 2014), pots were removed from the greenhouse and placed under a shade structure consisting of white mesh shade cloth with $40 \%$ shading. Pots were irrigated three times daily for $15 \mathrm{~min}$ to keep soil water close to field capacity. Weeds were controlled manually and lambda-cyhalothrin (5\% w/v, $10 \mathrm{~cm}^{3} \mathrm{~L}^{-1}$ water, Karate Zeon, Syngenta, Basel, Switzerland) and dimethoate + permethrin (dimethoate $5 \% \mathrm{w} / \mathrm{v}+$ permethrin $1.3 \% \mathrm{w} / \mathrm{v}, 2 \mathrm{~cm}^{3} 10 \mathrm{~L}^{-1}$ water, Dimetoato Plus, Anasac, Chile) were applied to control aphids. Pots were placed outdoors (22 December 2014) $28 \mathrm{~d}$ after planting, and plants were cut to a 2-cm stubble height.

\section{Dry matter production and botanical composition}

The DM production of the field experiment was measured by cutting at 3 to $5 \mathrm{~cm}$ aboveground with a cutting bar. A $1.0 \mathrm{~m}$ wide by $4.0 \mathrm{~m}$ long strip was cut in each experimental plot. A composite fresh herbage sample of approximately $200 \mathrm{~g}$ was taken from each treatment to determine botanical composition (manual separation) and DM percentage of PR, WC, and spontaneous species (drying at $70{ }^{\circ} \mathrm{C}$ for $48 \mathrm{~h}$ ). Nutrient efficiency was evaluated for the DM production of two experimental periods during the 2011-2012 growing season: August and September 2011 (spring) and January and February 2012 (summer). There was one regrowth and cutting per period. The DM of each botanical component (PR and WC) was determined in the pot experiment by cutting when plant regrowth reached a height of $20 \mathrm{~cm}$, leaving a $1-\mathrm{cm}$ stubble for the second and third cuttings (the first was not evaluated), which corresponded to the growth from January to March 2015.

\section{Soil nutrient availability}

To determine $\mathrm{N}$ and $\mathrm{P}$ absorption efficiency (NAE, PAE), soil $\mathrm{N}$ and $\mathrm{P}$ availability were evaluated at the $0-10 \mathrm{~cm}$ depth before regrowth started in each evaluation period (spring and summer) during the 2011-2012 growing season in the field and January 2015 in the pots, including $\mathrm{K}$ and its corresponding KAE (Table 3). Mineral $\mathrm{N}\left(\mathrm{N}_{-} \mathrm{NH}_{4}\right.$ and $\mathrm{N}-\mathrm{NO}_{3}$ ) was extracted with $\mathrm{KCl}_{2} \mathrm{~mol} \mathrm{~L}^{-1}(1: 10 \mathrm{w} / \mathrm{v})$ and determined by colorimetry by nitrate reduction to nitrite with $\mathrm{Cd} / \mathrm{Cu}$ and flux injection segmented with an autoanalyzer (Skalar SA 4000, Skalar Analytical B.V., Breda, The Netherlands). Available P (Olsen-P) was extracted with $\mathrm{NaHCO}_{3} 0.5 \mathrm{~mol} \mathrm{~L}^{-1}$ and quantified by colorimetry of ascorbic acid with a Skalar SA 4000 autoanalyzer. Potassium was extracted with ammonium acetate $\left(1 \mathrm{~mol} \mathrm{~L}^{-1}, \mathrm{pH} 7\right)$ followed by emission spectroscopy and atomic absorption (Sadzawka et al., 2006).

\section{Herbage nutrient concentration}

The herbage samples used to determine DM were ground to $<1 \mathrm{~mm}$ for nutrient concentration analyses. The $\mathrm{N}$ and $\mathrm{P}$ concentrations of plant tissues were determined in composite samples of subsamples from the two cuttings with weight 
Table 3. Soil nutrient availability at the $0-10 \mathrm{~cm}$ depth in field and pot experiments at the beginning of the evaluation of $\mathbf{N}, \mathbf{P}$, and $\mathrm{K}$ absorption efficiency.

\begin{tabular}{|c|c|c|c|c|c|c|}
\hline \multirow[b]{2}{*}{ Soil nutrient } & \multicolumn{2}{|c|}{ DSS } & \multicolumn{2}{|c|}{ SSS } & \multicolumn{2}{|c|}{ Pot } \\
\hline & 30 Jul 2011 & 4 Jan 2012 & 30 Jul 2011 & 12 Jan 2012 & 27 Jan 2015 & 23 Feb 2015 \\
\hline & $-\mathrm{mg}$ & 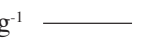 & $-\mathrm{mg}$ & {[} & $\longrightarrow \mathrm{mg}$ & - \\
\hline $\mathrm{N}$ & 11.0 & 24.9 & 10.0 & 27.8 & 8.1 & 15.7 \\
\hline $\mathrm{P}$ & 22.1 & 16.4 & 19.7 & 16.5 & 11.0 & 9.7 \\
\hline K & 216.0 & & 57.8 & & 91.3 & 105.6 \\
\hline
\end{tabular}

DSS: Deep soil site; SSS: shallow soil site; Pot: pot experiment.

Table 4. Nitrogen, phosphorus, and potassium concentration in plant tissue harvested at the end of the evaluation of nutrient absorption efficiency in field and pot experiments.

\begin{tabular}{|c|c|c|c|c|c|c|c|c|c|c|}
\hline \multirow[b]{3}{*}{ Nutrient } & \multicolumn{4}{|c|}{ DSS } & \multicolumn{4}{|c|}{ SSS } & \multirow{2}{*}{\multicolumn{2}{|c|}{$\frac{\text { Pot }}{23 \text { Feb } 2015}$}} \\
\hline & \multicolumn{2}{|c|}{30 Sep 2011} & \multicolumn{2}{|c|}{ 07 Feb 2012} & \multicolumn{2}{|c|}{17 Oct 2011} & \multicolumn{2}{|c|}{13 Feb 2012} & & \\
\hline & PR & WC & PR & WC & PR & WC & PR & WC & PR & WC \\
\hline & & - & $\mathrm{M}-$ & 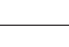 & 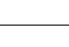 & $-\%$ & $M-$ & - & $-c$ & $\mathrm{M}$ \\
\hline $\mathrm{N}$ & 2.29 & 4.38 & 2.42 & 3.38 & 1.55 & 3.71 & 2.15 & 3.48 & 1.88 & 3.20 \\
\hline $\mathrm{P}$ & 0.41 & 0.29 & 0.45 & 0.27 & 0.26 & 0.23 & 0.41 & 0.27 & 0.45 & 0.22 \\
\hline K & & & & & & & & & 2.16 & 0.99 \\
\hline
\end{tabular}

DSS: Deep soil site; SSS: shallow soil site; Pot: potted experiment; PR: perennial ryegrass; WC: white clover.

in proportion to DM yield per cutting for each species in the field experiment. Total $\mathrm{N}$ in herbage was determined by the Kjeldahl method. The P concentration was determined by phosphovanadomolybdate calcination and colorimetry (Sadzawka et al., 2007). The K concentration was determined by atomic absorption spectrophotometry (Sadzawka et al., 2007).

\section{Nutrient absorption and use efficiency}

Absorption (NAE, PAE, and KAE) and use (NUE, PUE, and KUE) efficiency for N, P, and K, respectively, were calculated according to the procedure used by Acuña and Inostroza (2013) to evaluate the P efficiency of WC. Nutrient absorption (DM production $\times$ nutrient concentration in DM, Table 4) was expressed as $\mathrm{kg}$ absorbed nutrient ha ${ }^{-1} \mathrm{and}_{\mathrm{mg} \mathrm{pot}}{ }^{-1}$ for field and pot results, respectively. Nutrient absorption efficiency was calculated by dividing the amount of absorbed nutrient (nutrient absorption) by the amount of available soil nutrient at the beginning of regrowth (Table 4), which was expressed as $\mathrm{kg} \mathrm{ha}^{-1} / \mathrm{mg} \mathrm{kg}^{-1}$ or $\mathrm{g} \mathrm{pot}^{-1} / \mathrm{mg} \mathrm{kg}^{-1}$. Nutrient use efficiency was calculated by dividing DM production by nutrient absorption using the expressions $\mathrm{kg} \mathrm{DM} \mathrm{ha}{ }^{-1} / \mathrm{kg}$ absorbed nutrient ha- ${ }^{-1}$ and $\mathrm{g} \mathrm{DM} \mathrm{pot} / 1 / \mathrm{mg}$ absorbed nutrient pot ${ }^{-1}$ for field and pot experiments, respectively.

\section{Statistical analyses}

The ANOVA of DM yield and N, P, and K absorption and use efficiency for PR, WC, and their mixtures were performed with the SAS statistical software (SAS Institute, Cary, North Carolina, USA) according to the experimental design; only two blocks were considered for field $\mathrm{N}$ and $\mathrm{P}$ efficiency. Therefore, the effects of the ryegrass and clover cultivars and Ryegrass cultivar $\times$ Clover cultivar interaction were determined.

\section{RESULTS}

\section{Dry matter yield}

Interactions between the PR and WC factors were nonsignificant for DM yield, but the main effects were significant. The DM yield of PR 'Bealey' and 'Extreme' was significantly higher than for 'Banquet' and 'Quartet' in both field soil environments, whereas 'Bealey' showed the highest yield in pots (Table 5). The PR yields were higher $(\mathrm{P}<0.001)$ when mixed with WC 'Will' in the field at DSS and SSS, but did not significantly vary in the pots $(\mathrm{P}>0.05)$ with WC cultivars. The WC DM was not affected by the PR cultivar under the field or pot conditions, except for 'Bealey' that produced lower WC DM $(\mathrm{P}<0.05)$ than other cultivars at SSS. Mean DM yields of WC cultivars did not vary at DSS but varied at SSS in the field experiment, whereas 'Will' yielded significantly more than 'Bounty' and 'Ladino' in the pot experiment. 
Table 5. Dry matter production means of perennial ryegrass (PR) and white clover (WC) cultivars, mixtures (PR + WC), and their total, means of spring (Sep-Oct) and summer (Feb-Mar) 4-wk periods under deep (DSS) and shallow soil site (SSS) conditions, and two summer cutting periods (Jan-Mar) in pots (Pot).

\begin{tabular}{|c|c|c|c|c|c|c|c|c|c|c|c|}
\hline & \multicolumn{8}{|c|}{ Field experiments } & \multirow{2}{*}{\multicolumn{3}{|c|}{$\begin{array}{c}\text { Pot experiment } \\
\text { Pot }\end{array}$}} \\
\hline & \multicolumn{4}{|c|}{ DSS } & \multicolumn{4}{|c|}{ SSS } & & & \\
\hline & PR & WC & $\mathrm{PR}+\mathrm{WC}$ & Total & PR & WC & $\mathrm{PR}+\mathrm{WC}$ & Total & PR & WC & $\mathrm{PR}+\mathrm{WC}$ \\
\hline & 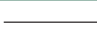 & - $\mathrm{kg} \mathrm{I}$ & $\mathrm{ha}^{-1}$ & - & 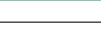 & $-\mathrm{kg} \mathrm{D}$ & $\mathrm{ha}^{-1}$ & 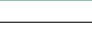 & $\longrightarrow$ & DM pot & - \\
\hline \multicolumn{12}{|l|}{ PR cultivars } \\
\hline Banquet & 1069 & 1644 & 2713 & 2982 & 1075 & 352 & 1427 & 2075 & 5.1 & 34.3 & 39.3 \\
\hline Bealey & 1163 & 1539 & 2702 & 2857 & 1219 & 289 & 1508 & 2379 & 8.5 & 32.4 & 40.9 \\
\hline Extreme & 1322 & 1599 & 2920 & 3111 & 1169 & 394 & 1563 & 2311 & 5.3 & 39.1 & 44.4 \\
\hline Quartet & 1085 & 1441 & 2526 & 2675 & 882 & 323 & 1205 & 1840 & 6.6 & 32.1 & 38.8 \\
\hline Sign. & $* *$ & ns & ns & ns & $* * *$ & $*$ & ns & $* *$ & $* * *$ & ns & ns \\
\hline SE & 60.9 & 77.1 & 134.1 & 143.4 & 77.4 & 24.9 & 97.4 & 123.7 & 0.36 & 1.96 & 1.96 \\
\hline \multicolumn{12}{|l|}{ WC cultivars } \\
\hline Ladino & 946 & 1603 & 2549 & 2726 & 968 & 175 & 1143 & 1864 & 6.2 & 30.6 & 36.8 \\
\hline Will & 1429 & 1641 & 3070 & 3289 & 1364 & 661 & 2025 & 2673 & 6.4 & 38.0 & 44.4 \\
\hline Bounty & 1105 & 1423 & 2528 & 2705 & 926 & 182 & 1108 & 1917 & 6.5 & 34.9 & 41.4 \\
\hline Sign. & *** & ns & *** & *** & $* * *$ & $* * *$ & $* * *$ & $* * *$ & ns & $* *$ & $* *$ \\
\hline SE & 52.8 & 66.8 & 116.1 & 124.2 & 67.1 & 21.5 & 84.4 & 107.2 & 0.31 & 1.70 & 1.70 \\
\hline
\end{tabular}

PR: Perennial ryegrass; WC: white clover; PR+WC: ryegrass + white clover mixture; Total: PR+WC + other species.

Sign.: significance according to the $\mathrm{F}$ test.

$*, * *, * * *$ Significant at $0.05,0.01$, and 0.001 probability levels, respectively; ns: nonsignificant; SE: standard error.

\section{Nutrient absorption efficiency}

The nutrient absorption efficiency results are shown in Table 6. Interactions between the PR and WC factors were nonsignificant. The PR factor did not affect the nutrient absorption efficiency of PR, except at DSS in the field experiment in which 'Extreme' and 'Bealey' tended to be more efficient than 'Quartet' and 'Banquet'. The nutrient absorption efficiency of PR was higher $(\mathrm{P}<0.01)$ when mixed with WC 'Will' in the field experiment, but the WC factor did not affect it in PR in the pot experiment. Results for WC varied between sites. In the field experiment, the nutrient absorption efficiency of 'Will' tended to be similar to the other cultivars at DSS, but it was significantly higher than 'Ladino' and 'Bounty' at SSS. The nutrient absorption efficiency of WC in pots was lower for 'Ladino' than 'Will' and 'Bounty', which were similar (Table 6). For the mixture (PR + WC) containing WC 'Will', it was significantly higher than mixtures with 'Ladino' or 'Bounty' in the field at SSS where the mean was very low compared with DSS. The WC 'Bounty' mixtures in pots reached the highest efficiency.

Table 6. Nitrogen absorption efficiency of perennial ryegrass (PR) and white clover (WC) cultivars, PR + WC mixtures, means of spring (Sep-Oct) and summer (Feb-Mar) 4-wk periods under deep (DSS) and shallow soil site (SSS) conditions, and two summer cutting periods (Jan-Mar) in pots (Pot).

\begin{tabular}{|c|c|c|c|c|c|c|c|c|c|}
\hline & \multicolumn{6}{|c|}{ Field experiments } & \multirow{2}{*}{\multicolumn{3}{|c|}{$\begin{array}{c}\text { Pot experiment } \\
\text { Pot }\end{array}$}} \\
\hline & \multicolumn{3}{|c|}{ DSS } & \multicolumn{3}{|c|}{ SSS } & & & \\
\hline & PR & WC & $\mathrm{PR}+\mathrm{WC}$ & PR & WC & $\mathrm{PR}+\mathrm{WC}$ & PR & WC & $\mathrm{PR}+\mathrm{WC}$ \\
\hline & & & $\mathrm{N}$ abs ha- & $\mathrm{N} \mathrm{kg}^{-1} \mathrm{SC}$ & & & & $\operatorname{pot}^{-1 / m g}$ & $\mathrm{~g}^{-1}$ soil \\
\hline \multicolumn{10}{|l|}{ PR cultivars } \\
\hline Banquet & 0.86 & 2.30 & 3.16 & 0.62 & 0.39 & 1.00 & 13.4 & 141.3 & 154.8 \\
\hline Bealey & 0.96 & 2.17 & 3.12 & 0.72 & 0.29 & 1.02 & 16.1 & 125.0 & 141.1 \\
\hline Extreme & 1.09 & 2.32 & 3.40 & 0.69 & 0.41 & 1.10 & 13.2 & 158.8 & 172.0 \\
\hline Quartet & 0.84 & 1.97 & 2.81 & 0.53 & 0.33 & 0.86 & 15.4 & 131.1 & 146.5 \\
\hline Sign. & $* *$ & $\mathrm{~ns}$ & ns & ns & ns & ns & ns & ns & ns \\
\hline SE & 0.055 & 0.041 & 0.183 & 0.057 & 0.034 & 0.085 & 0.98 & 9.55 & 9.87 \\
\hline \multicolumn{10}{|l|}{ WC cultivars } \\
\hline Ladino & 0.87 & 2.29 & 3.15 & 0.54 & 0.19 & 0.72 & 13.7 & 118.7 & 132.4 \\
\hline Will & 1.05 & 2.33 & 3.38 & 0.81 & 0.70 & 1.51 & 13.8 & 145.6 & 159.4 \\
\hline Bounty & 0.88 & 1.95 & 2.83 & 0.57 & 0.18 & 0.75 & 16.1 & 152.9 & 169.0 \\
\hline Sign. & $* *$ & $*$ & ns & $* * *$ & $* * *$ & $* * *$ & ns & ** & ** \\
\hline SE & 0.048 & 0.035 & 0.158 & 0.049 & 0.030 & 0.074 & 0.85 & 8.27 & 8.55 \\
\hline
\end{tabular}

PR: Perennial ryegrass; WC: white clover; PR+WC: ryegrass + white clover mixture; Total: PR+WC + other species. Sign.: Significance according to the $\mathrm{F}$ test.

$*, * *, * * *$ Significant at $0.05,0.01$, and 0.001 probability levels, respectively; ns: nonsignificant; SE: standard error. 
Table 7 displays the results for PAE; it only shows the cultivar means because the PR $\times$ WC interaction was not significant for any of the PAE results. The PR cultivar factor only significantly affected the PAE of the PR botanical component of mixtures in the field at DSS and in the pots in which 'Extreme' and 'Bealey' reached the highest PAE values, respectively. The WC cultivar factor significantly affected the PAE of PR at both DSS and SSS in the field, but not in the pots $(\mathrm{P}>0.05)$. Meanwhile, the WC PAE significantly differed among cultivars under the field and pot conditions; 'Will' reached significantly higher values than 'Ladino' and 'Bounty' at DSS and SSS, and 'Will' and 'Bounty' showed similar PAE with higher $(\mathrm{P}<0.01)$ values than 'Ladino' in pots (Table 7). The PAE of mixtures $(\mathrm{PR}+\mathrm{WC})$ containing WC 'Will' reached significantly higher values $(\mathrm{P}<0.001)$ than mixtures with 'Ladino' or 'Bounty' in the field at both soil sites, but mixtures with 'Bounty' were higher than with 'Ladino' in the pots $(\mathrm{P}<0.01)$.

The interactions between PR and WC factors for KAE, which were only evaluated under pot conditions, were nonsignificant $(\mathrm{P}>0.05)$. The PR factor affected the KAE of PR and WC. The PR 'Bealey' and 'Quartet' produced higher PR KAE than 'Banquet' and 'Extreme'. The KAE of WC was higher $(\mathrm{P}<0.01)$ for PR 'Extreme' than for other PR cultivars, which exhibited similar values. The WC factor did not significantly affect the KAE of PR or WC (P>0.05). The KAE of the mixture (PR + WC) was not affected by PR or WC factors (Figure 1).

\section{Nutrient use efficiency}

No interactions between PR and WC factors were found for NUE, PUE, or KUE. The PR 'Quartet' had the lowest PR NUE in the field experiment at both DSS and SSS $(\mathrm{P}<0.05$ at SSS). The PR 'Bealey' had the highest PR NUE $(\mathrm{P}<0.05)$ in the pot experiment. The WC 'Ladino' reached the highest values of WC NUE in the field, particularly at SSS $(\mathrm{P}<0.01)$, but 'Will' reached the highest values in the pots. The NUE of the mixture $(\mathrm{PR}+\mathrm{WC})$ showed lower values when WC cultivars were associated with PR 'Quartet' and when PR cultivars were associated with WC 'Will' at SSS. In the pot study, mixtures containing PR 'Banquet' and WC 'Bounty' exhibited the lowest NUE values in mixtures (Figure 2). The PR PUE results showed that PR 'Quartet' was the least efficient in the field experiment $(\mathrm{P}<0.05$ at DSS). The PR 'Extreme' was the most efficient $(\mathrm{P}<0.05)$ in pots. The WC 'Ladino' had higher WC PUE in the field at DSS and SSS $(\mathrm{P}<0.05)$. However, WC 'Will' had higher WC PUE in pots. The PUE of the mixture $(\mathrm{PR}+\mathrm{WC})$ was significantly higher for the combinations containing PR 'Bealey' at DSS or WC 'Ladino' at both soil depths of the field experiment. The PR KUE of 'Bealey' showed the highest value $(\mathrm{P}<0.05)$ among PR cultivars and the WC KUE means did not significantly differ (Figure 1).

Table 7. Phosphorus absorption efficiency of perennial ryegrass (PR), white clover (WC) cultivars, and PR+WC mixtures), means of spring (Sep-Oct) and summer (Feb-Mar) 4-wk periods under deep (DSS) and shallow soil site (SSS) conditions, and two summer cutting periods (Jan-Mar) in pots (Pot).

\begin{tabular}{|c|c|c|c|c|c|c|c|c|c|}
\hline & \multicolumn{6}{|c|}{ Field experiments } & \multirow{2}{*}{\multicolumn{3}{|c|}{$\frac{\text { Pot experiment }}{\text { Pot }}$}} \\
\hline & \multicolumn{3}{|c|}{ DSS } & \multicolumn{3}{|c|}{ SSS } & & & \\
\hline & PR & WC & $\mathrm{PR}+\mathrm{WC}$ & PR & WC & $\mathrm{PR}+\mathrm{WC}$ & PR & WC & $\mathrm{PR}+\mathrm{WC}$ \\
\hline & & & g P abs ha- & $\mathrm{kg}^{-1}$ soi & & 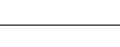 & & $\mathrm{ot}^{-1 / m g}$ & $g^{-1}$ soil \\
\hline \multicolumn{10}{|l|}{ PR cultivars } \\
\hline Banquet & 0.12 & 0.12 & 0.24 & 0.10 & 0.03 & 0.12 & 2.4 & 6.9 & 9.4 \\
\hline Bealey & 0.12 & 0.11 & 0.23 & 0.11 & 0.02 & 0.13 & 3.2 & 6.4 & 9.6 \\
\hline Extreme & 0.15 & 0.12 & 0.27 & 0.11 & 0.03 & 0.14 & 2.0 & 7.9 & 9.8 \\
\hline Quartet & 0.13 & 0.10 & 0.24 & 0.10 & 0.02 & 0.12 & 2.4 & 6.6 & 9.3 \\
\hline Sign. & ** & ns & ns & ns & $\mathrm{ns}$ & ns & $* * *$ & ns & $\mathrm{ns}$ \\
\hline $\mathrm{SE}$ & 0.007 & 0.006 & 0.013 & 0.006 & 0.002 & 0.008 & 0.16 & 0.48 & 0.56 \\
\hline \multicolumn{10}{|l|}{ WC cultivars } \\
\hline Ladino & 0.10 & 0.11 & 0.22 & 0.09 & 0.01 & 0.11 & 2.6 & 5.9 & 8.5 \\
\hline Will & 0.17 & 0.13 & 0.30 & 0.13 & 0.05 & 0.19 & 2.5 & 6.9 & 9.4 \\
\hline Bounty & 0.12 & 0.11 & 0.22 & 0.08 & 0.01 & 0.10 & 2.7 & 8.0 & 10.6 \\
\hline Sign. & $* * *$ & $* *$ & $* * *$ & $* * *$ & $* *$ & $* * *$ & $\mathrm{~ns}$ & $\mathrm{~ns}$ & $* *$ \\
\hline $\mathrm{SE}$ & 0.006 & 0.005 & 0.011 & 0.005 & 0.002 & 0.007 & 0.14 & 0.41 & 0.48 \\
\hline
\end{tabular}

PR: Perennial ryegrass; WC: white clover; PR+WC: ryegrass + white clover mixture; Total: PR+WC + other species. Sign.: Significance according to the $\mathrm{F}$ test.

$*, * *, * * *$ Significant at $0.05,0.01$, and 0.001 probability levels; ns: nonsignificant; SE: standard error. 
Figure 1. Potassium absorption efficiency (KAE) and potassium use efficiency (KUE) of perennial ryegrass (PR), and white clover (WC) cultivars and PR+WC mixtures in pots for two summer cutting periods (Jan-Mar).
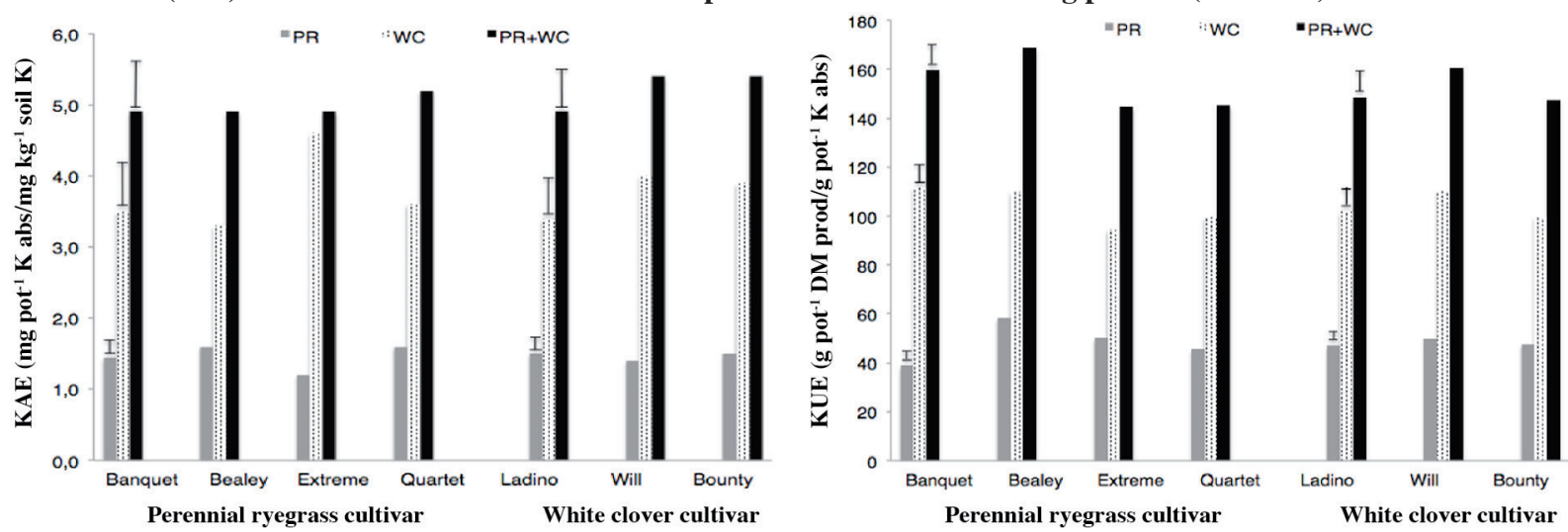

Vertical bars represent standard error for comparisons within each species.

Figure 2. Nitrogen (NUE) and phosphorus use efficiency (PUE) of perennial ryegrass (PR), white clover (WC) cultivars, and PR+WC mixtures, cultivar means of spring (Sep-Oct) and summer (Feb-Mar) 4-wk periods under deep (DSS) and shallow soil site (SSS) conditions, and in pots (Pot) for two summer cutting periods (Jan-Mar).

DSS
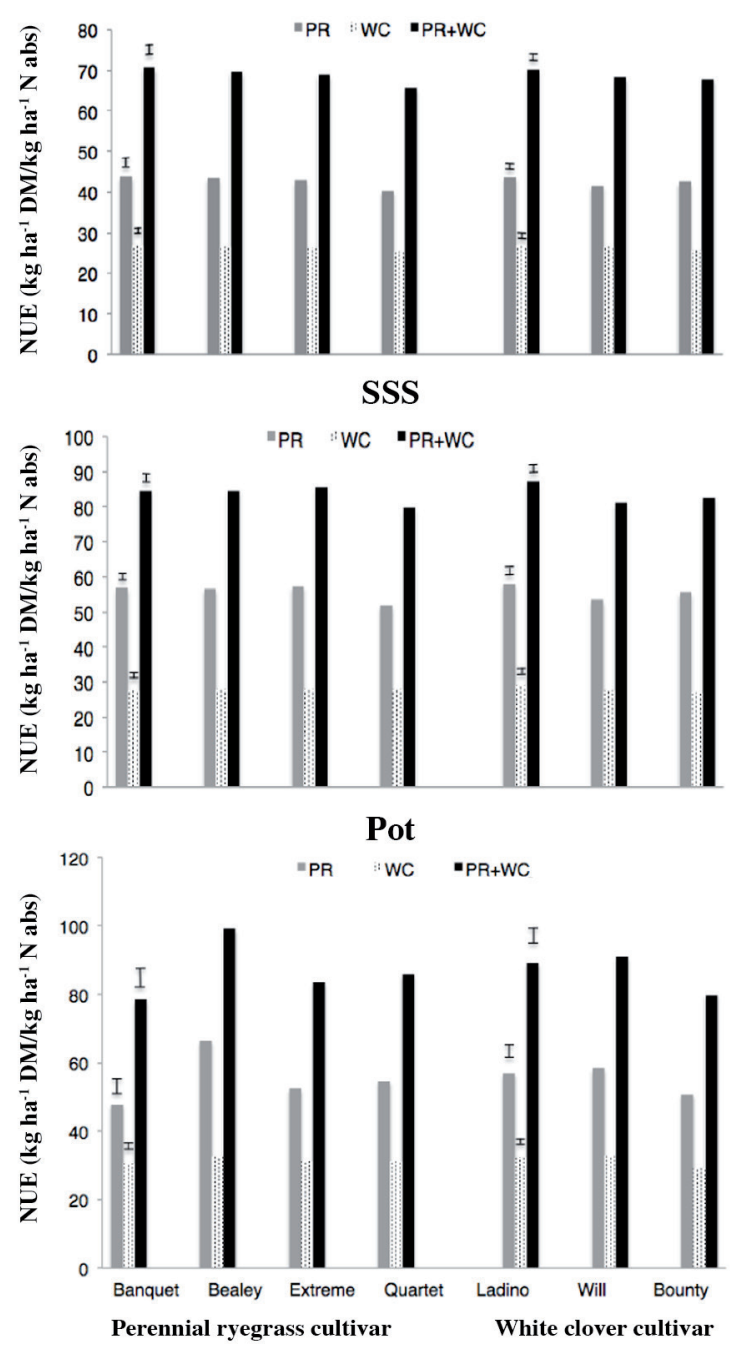

DSS
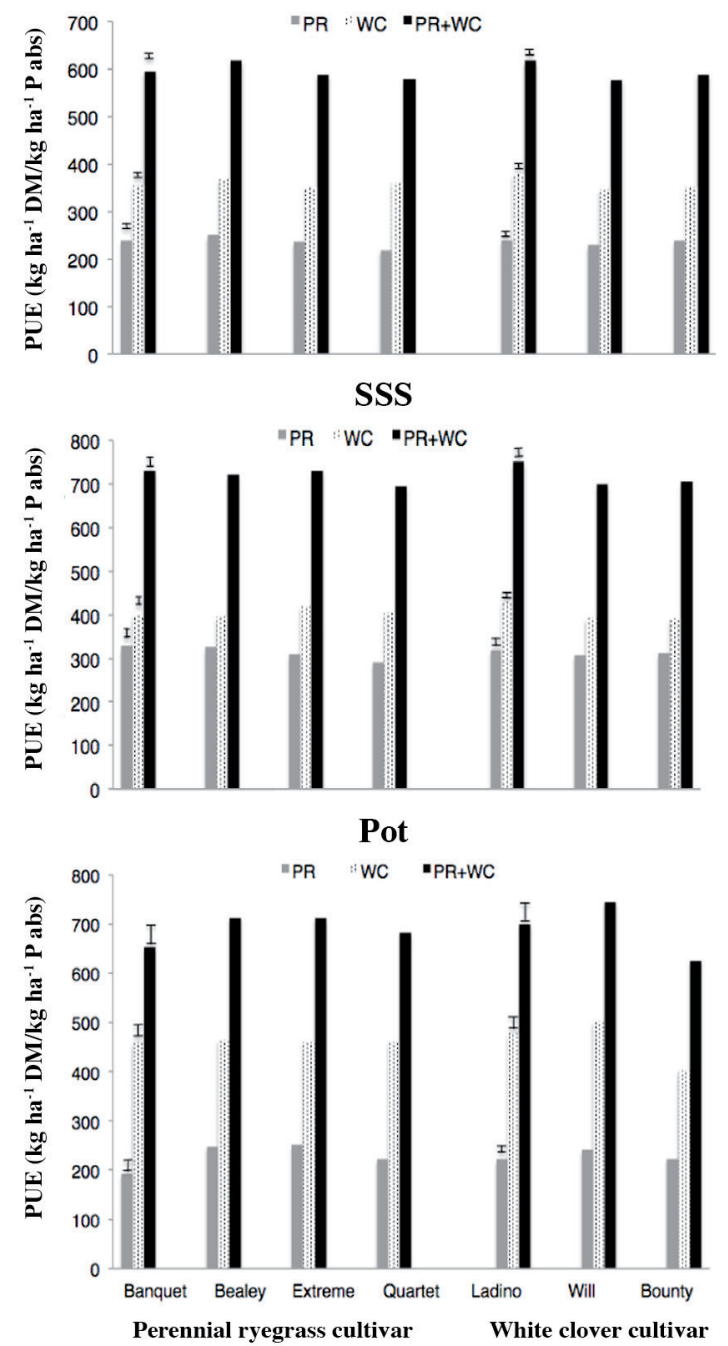

Vertical bars represent standard error for comparisons within each species. 


\section{DISCUSSION}

\section{Dry matter yields}

The PR 'Bealey' DM yield reached the highest values when field and pot results were considered, and the negative effect of Bealey on the WC yield at SSS tended to be stronger than for the other PR cultivars (5). The high yield potential of 'Bealey' has also been reported in other works (Kerr et al., 2012; Evans and Hall, 2013), which confirm the results obtained in the present study, particularly in pots.

Decreased WC yield at SSS when 'Bealey' was part of the mixture is evidence that this cultivar is a strong competitor in soils with depth limitations, which can affect the root system of both species and intensify interspecific competition for water and nutrients (Hoekstra et al., 2015; Suter et al., 2015). A higher NAE (Table 6) exhibited by 'Bealey' under field and pot conditions can explain the abovementioned results. Inostroza et al. (2015) reported that the NUE of 'Bealey' was high under both low and high $\mathrm{N}$ availability, which was associated with a higher root DM production.

The periods selected to evaluate nutrient efficiency covered the cumulative growth in two cuttings because of the close interdependence between cultivar DM yield and cultivar nutrient efficiency. In the field experiment, yields corresponded to two periods (spring and summer), which represented the growth of mixtures under contrasting environmental conditions within the growing season; this promoted grass (spring) and legume (summer) growth to obtain a mean nutrient efficiency that was more representative of the seasonal performance of each species. Yields in pots correspond to two successive cuttings after complete mixture establishment. The selection of these periods to measure DM yields appears to have allowed the mixtures to reach reliable values for comparing cultivar effects on nutrient efficiency. The difference in the performance of the WC 'Will' mean yields at DSS (equal to 'Ladino' and 'Bounty', P>0.05) compared with SSS, which reached the highest value $(\mathrm{P}<0.001)$, shows that this WC cultivar can compete better against $\mathrm{PR}$ than the large- and small-leaved WC cultivars (Table 5). This was consistent with the higher NAE and PAE for 'Will' (Tables 6 and 7), but an association with $\mathrm{N}$ or $\mathrm{P}$ use efficiency was not found (Figures 1 and 2).

\section{Nutrient use efficiency}

The contrasting values reached by WC NAE of the PR cultivar means at DSS vs. SSS (approximately 6:1, respectively) would be a consequence of lower soil water and nutrient availability and from the reduced water and plant nutrient uptake capacity, particularly clover. Under conditions of restricted root growth at SSS, ryegrass root development was probably less affected than the clover root system in mixtures, and its competitive ability against the legume increased. Hoekstra et al. (2015) found clear evidence of spatial niche differences in resource uptake between shallow- and deep-rooted species, which did not result in increased resource uptake; the soil water-holding capacity was higher at DSS than SSS because of its higher soil depth and the presence of stones in the profile and subsoil of SSS. The reduction in N uptake under water deficit conditions has been well documented for different species, including PR, and is due to two processes: (i) the reduction in crop $\mathrm{N}$ demand linked to the reduction in crop mass accumulation because of plant water stress and (ii) the reduction in soil $\mathrm{N}$ availability associated with soil water restriction (Lemaire and Ciampitti, 2020). However, in the present study, $\mathrm{N}$ availability cannot be associated with water supply because the same amount of water was applied in both experiments (field and pot) with no water restriction.

The original soil N, P, and K availability and soil organic matter content exhibited important deficiencies for plant growth at SSS (Table 2), particularly low K availability, which could not be entirely addressed by differential K fertilizer applications. The soil K deficiency strongly decreased $\mathrm{WC}$ growth, and affected its $\mathrm{N}$ fixation efficiency and $\mathrm{P}$ absorption (Hogh-Jensen and Schjoerring, 2010; Luscher et al., 2019).

The higher biological N fixation capacity of WC 'Will' could explain the smaller difference of NAE for 'Will' between DSS and SSS compared with larger differences between the NAE for 'Ladino' and 'Bounty' at the two sites. The means of PR NAE for WC 'Will' were higher than for 'Ladino' and 'Bounty' at both sites in the field, but did not differ in pots; this could be related to better nutrient and water availability under more controlled conditions (Hoekstra et al., 2015).

The effect of the WC cultivar on WC and PR PAE (Table 7) was similar at the two field sites; the means for 'Will' reached the highest PAE, and the lack of this effect in the pot experiment likely corresponds to better water and nutrient availability as reported by Castillo et al. (2013) in their work with Lotus spp. However, soil nutrient availability values (Table 4) showed lower N, P, and K contents in the soil of the pots compared with the field; this could indicate that the 
different response of NAE was affected more by soil water availability than soil nutrient content, given that soil water was subjected to greater control.

The KAE, which was measured only in the pot experiment, did not show significant differences for the means of WC or PR and followed the same pattern as PAE. Given that the pot experiment was primarily conducted to verify the field results under conditions where the factors (PR and WC cultivars) were managed without the presence of spontaneous species or other uncontrolled environmental variables such as short periods of excessively high temperatures or soil water deficit, the contribution of the pot results seems to be less useful than expected.

The nutrient use efficiency results (Figures 1 and 2) showed little effect of the cultivar in both species; however, there are some general trends. The NUE, PUE, and KUE for PR 'Quartet' were low under all conditions. The WC 'Ladino' showed higher NUE and PUE under field conditions, particularly at SSS, than the other WC cultivars, whereas WC 'Will' reached higher NUE, PUE, and KUE values under pot conditions. On the basis of species, PR NUE was higher than WC NUE by approximately 30\% under all conditions. The WC PUE was higher than the PR PUE, but ample differences were observed between field sites and between field and pot experiments. The WC PUE in pots doubled the values reached by PR; at DSS in the field, the differences decreased to approximately $50 \%$ of PR PUE and the differences at SSS did not surpass 20\%. No differences in nutrient use efficiency between cultivars of both species were found in the literature. References in the literature on the nutrient efficiency of forage species, particularly perennial species for permanent grassland, are scarce compared with the abundance for crop species that need different conceptualizations and methodologies to evaluate nutrient efficiency. When analyzing the current situation, Weih et al. (2018) stated that several indices were applied to evaluate the nutrient (mostly $\mathrm{N}$ ) use efficiency of plants, but these indices have rarely been compared across different crops, and the co-limitation of growth by nutrients other than $\mathrm{N}$ was not usually studied.

\section{CONCLUSIONS}

The results show a cultivar effect on the nutrient efficiency of perennial ryegrass/white clover mixtures. The pot evaluation did not improve the interpretation of field results as expected because of the weakness of the cultivar effect on the nutrient efficiency of the companion species. This may indicate that the evaluation of the field experiment could be biased by uncontrolled environmental conditions, particularly the proportion of spontaneous species that might not affect all cultivars in a similar way. The impact of cultivar nutrient absorption efficiency on perennial ryegrass-white clover compatibility in mixed swards is a functional attribute as evidenced here by higher absorption efficiency for perennial ryegrass 'Bealey' and white clover 'Will' and 'Bounty', which exhibit the highest degree of compatibility for total DM yield.

\section{ACKNOWLEDGEMENTS}

The authors thank José Oñate, Catalina Vásquez, and Valentina Sánchez for their assistance. This work is part of a thesis project by the first author M.P.S. in the Programa de Magister en Ciencias Agropecuarias, Universidad de Concepción. This study was supported by a postgraduate scholarship from CONICYT, Chile.

\section{REFERENCES}

Acuña, H., and Inostroza, L. 2013. Phosphorus efficiency of naturalized Chilean white clover in a grazed field trial. Grass and Forage Science 68(1):125-137. doi:10.1111/j.1365-2494.2012.00879.x.

Acuña, H., Inostroza, L., Pinochet, D., Balocchi, O., Ortega, F., Lopez, R., et al. 2016. White clover (Trifolium repens L.) germplasm selection for abiotic stress tolerance from naturalized populations collected in the Southern Regions of Chile. p. 81-87. In Roldán-Ruiz, I., Baert, J., and Reheul, D. (eds.) Breeding in a world of scarcity: Proceedings of the 2015 Meeting of the Section "Forage Crops and Amenity Grasses" of Eucarpia. Springer International Publishing, Cham, Switzerland.

Annicchiarico, P., Barrett, B., Brummer, E.C., Julier, B., and Marshall, A.H. 2015. Achievements and challenges in improving temperate perennial forage legumes. Critical Reviews in Plant Sciences 34(1-3):327-380. doi:10.1080/07352689.2014.898462.

Barrett, B.A., Faville, M.J., Nichols, S.N., Simpson, W.R., Bryan, G.T., and Conner, A.J. 2015. Breaking through the feed barrier: Options for improving forage genetics. Animal Production Science 55:883-892. 
Blair, G. 1993. Nutrient efficiency-what do we really mean? p. 205-213. In Randall, J. (ed.) Genetic aspects of plant mineral nutrition. Kluwer Academic Publishers, Dordrecht, The Netherlands.

Castillo, C., Acuña, H., Zagal, E., and Inostroza, L. 2013. Phosphorus absorption and use efficiency by Lotus spp. Under water stress conditions in two soils: A pot experiment. Chilean Journal of Agricultural Research 73:31-40. doi:10.4067/S0718-58392013000100005.

Evans, P., and Hall, E. 2013. Hybrid and perennial tetraploid ryegrasses are at least as productive and persistent as perennial diploids in dryland conditions in northern Tasmania. p. 303-304. In Michalk, D.L., Millar, G.D., Badgery, W.B. and Broadfoot, K.M. (eds.) Proceedings 22 ${ }^{\text {nd }}$ International Grassland Congress, Sydney. 15-19 September. New South Wales Department of Primary Industry, Orange, New South Wales, Australia.

Hoekstra, N.J., Suter, M., Finn, J.A., Husse, S., and Luscher A. 2015. Do belowground vertical niche differences between deepand shallow-rooted species enhance resource uptake and drought resistance in grassland mixtures? Plant and Soil 394:21-34.

Hogh-Jensen, H., and Schjoerring, J.K. 2010. Interactions between nitrogen, phosphorus and potassium determine growth and $\mathrm{N}_{2}$-fixation in white clover and ryegrass leys. Nutrient Cycling in Agroecosystems 87(3):327-338. doi:710.100/s10705-009-9341-0.

Husse, S., Luscher, A., Buchmann, N., Hoekstra, N.J., and Huguenin-Elie, O. 2017. Effects of mixing farage species contrasting in vertical and temporal nutrient capture on nutrient yields and fertilizer recovery in productive grasslands. Plant and Soil 420:505-521.

Inostroza, L., Bhakta, M., Acuña, H., Vásquez, C., Ibáñez, J., et al. 2018. Understanding the complexity of cold tolerance in white clover using temperature gradient locations and a GWAS approach. Plant Genome 11:170096. doi:10.3835/plantgenome2017.11.0096.

Inostroza, L., Ibañez, J., Ortega, F., Acuña, H., and Undurraga, P. 2015. Nitrogen use efficiency and root dry mater partitioning in four perennial temperate forage grass species. p. 2-4. In Roy, M.M., Malaviya, D.R., Yadav, V.K., Singh, T., Sah, R.P., Vijay, D., et al. (eds.) Proceedings of the XXIII International Grassland Congress, New Delhi. 20-24 November. Range Management Society of India, Jhansi, Uttar Pradesh, India.

Jahufer, M.Z.Z., Ford, J.L., Widdup, K.H., Harris, C., Cousins, G., Ayres, J.F., et al. 2012. Improving white clover for Australasia. Crop and Pasture Science 63(8-9):739-745. doi:10.1071/cp12142.

Kerr, G., Chapman, D., Thom, E., Matthew, C., Van der Linden, A., Baird, D.B., et al. 2012. Evaluating perennial ryegrass cultivars: improving testing. Proceedings of the New Zealand Grassland Association 74:127-136.

Lemaire, G., and Ciampitti, I. 2020. Crop mass and N status as prerequisite covariables for unraveling nitrogen use efficiency across genotype-by-environment-by-management scenarios: A review. Plants 9(10):1-19.

Luscher,A., Grieder, C., Huguenin-Elie, O., Klaus, V.H., Reidy, B., Schneider, M.K., et al. 2019. Grassland systems in Switzerland with a main focus on sown grasslands. Grassland Science in Europe 24:3-16. https://doi.org/10.3929/ethz-b-000353583.

Manschadi, A.M., Kaul, H.-P., Vollmann, J., Eitzinger, J., and Wenzel, W. 2014. Developing phosphorus-efficient crop varieties An interdisciplinary research framework. Field Crops Research 162:87-98. doi:10.1016/j.fcr.2013.12.016.

Nyfeler, D., Huguenin-Elie, O., Suter, M., Frossard, E., and Lüscher, A. 2011. Grass-legume mixtures can yield more nitrogen than legume pure stands due to mutual stimulation of nitrogen uptake from symbiotic and non-symbiotic sources. Agriculture Ecosystems and Environment 140(1):155-163. https://doi.org/10.1016/j.agee.2010.11.022.

Ramírez, C.A., and Worrell,E. 2006. Feeding fossil fuels to the soil: An analysis of energy embedded and technological learning in the fertilizer industry. Resources, Conservation and Recycling 46(1):75-93. https://doi.org/10.1016/j.resconrec.2005.06.004.

Sadzawka, M., Carrasco, M., Demanet, R., Flores, H., Grez, R., Mora, M., et al. 2007. Métodos de análisis de tejidos vegetales. $2^{a}$ ed. Serie Actas INIA N40. 140 p. Instituto de Investigaciones Agropecuarias (INIA), Santiago, Chile.

Sadzawka, M., Carrasco, M., Grez, R., Mora, M., Flores, H., y Neaman, A. 2006. Métodos de análisis de suelos recomendados para los suelos de Chile. Serie Actas INIA N³4. 146 p. Instituto de Investigaciones Agropecuarias (INIA), Santiago, Chile.

Stolpe, N.B. 2006. Descripciones de los principales suelos de la VIII Región de Chile. Departamento de Suelos, Facultad de Agronomía, Universidad de Concepción, Chillán, Chile.

Suter, M., Connolly, J., Finn, J.A., Loges, R., Kirwan, L., Sebastià, M.T., et al. 2015. Nitrogen yield advantage from grasslegume mixtures is robust over wide range and environmental conditions. Global Change Biology 21:2424-2438.

Thilakarathna, M.S., McElroy, M.S., Chapagain, T., Papadopoulos, Y.A., and Raizada, M.N. 2016. Below ground nitrogen transfer from legumes to non-legumes under managed herbaceous cropping systems. A review. Agronomy for Sustainable Development 36(4):58. doi:10.1007/s13593-016-0396-4.

Vásquez, C., Inostroza, L., and Acuña, H. 2018. Phenotypic variation of cold stress resistance-related traits of white clover populations naturalized in Patagonian cold environments. Crop Science 58(3):1132-1144. doi:10.2135/cropsci2017.07.0460.

Weih, M., Hamnér, K., and Pourazari, F. 2018. Analyzing plant nutrient uptake and utilization efficiencies: comparison between crops and approaches. Plant and Soil 430:7-21.

Wilkins, R.J. 2008. Eco-efficient approaches to land management: a case for increased integration of crop and animal production systems. Philosophical Transactions of the Royal Society of London. Series B, Biological Sciences 363(1491):517-525. doi:10.1098/rstb.2007.2167. 